\title{
The Politeness Realization of Opposing Speech Acts in Banjar Language Based on Brown and Stephen Levinson Scale
}

\author{
Jahdiah $^{1}$, Rissari Yayuk ${ }^{2}$, Siti Alfa Ariestya ${ }^{3}$ \\ diah.banjar@yahoo.co.id ${ }^{1}$, yrissariyayuk@yahoo.co.id ${ }^{2}$, akualfa2010@yahoo.com ${ }^{3}$ \\ Balai Bahasa Kalimantan Selatan, Loktabat Banjarbaru Kalimantan Selatan ${ }^{1}$, Balai \\ Bahasa Kalimantan Selatan, Loktabat Banjarbaru Kalimantan Selatan², Balai Bahasa \\ Kalimantan Selatan, Loktabat Banjarbaru Kalimantan Selatan ${ }^{3}$
}

\begin{abstract}
Language politeness is important to consider in communication. The problem in this study is how the realization of the application and violation of politeness utterances in the Banjar language based on the courtesy scale of Brown and Lavinson. This study aims to describe the realization of the application and violations of the politeness utterances. Descriptive research method. Data is taken from June to December 2019 in Kaliukan Village, Astambul Regency. The techniques used are observation, note taking, recording, and interview. Data were analyzed based on pragmatic theory. The results of the study are the opponent's utterance in the Banjar language has applications and language violations based on the Brown and Lavinson scale, namely 1) the scale of the speaker and speaker partner social distance levels, 2) the scale of the speaker social status and speaker partners 3) the scale of the speech act level.
\end{abstract}

Keywords: Speech Opposition, Politeness, Banjar Language

\section{Introduction}

Language has an important role in our lives. Every language is used as a communication tool. As a communication tool, language is used as a tool to deliver a massage from one person to another, or from speaker to listener, and from writer to a reader. Besides, people can express their ideas orally to the others. Language is the main tool for human to carry out their social life. In the communication context, language has a very close relation with culture in a complex way. Language which is used by human refers to their experiences. Through language human do communication to express fact, idea, or event based on their knowledge about world that they experience it together. Language also reflects the attitude and human point of view with the others (Jumanto, 2017:7). ${ }^{1}$

Language is a social activity. Like the other social activities, the activity of using language is formed when human is inside it. In speaking, the speaker and speaker partner realize that there are rules which manage their acts (Wijana, 1996:45)2. This phenomenon is studied in pragmatics. Putrayasa $\left(2015^{3}\right.$ stated that pragmatics is a branch of linguistics that study about language structure externally, that is how a certain lingual is used in real.

\footnotetext{
${ }^{1}$ PenelitiMadya

${ }^{2}$ PenelitiMadya

${ }^{3}$ Penerjemah Muda
} 
communication. Kridalaksana $(2010, p .2)^{4}$ stated that pragmatics is a science that analyzes speech act, context, and meaning.

According to Thomas, $(1996: 22)^{5}$ pragmatics is meaning inside interaction, the meaning is resulted as a dynamic process that covers meaning negotiation between speaker and speaker partner, utterance context (physically, socially, and linguistically), and the potential meaning in the utterance. Yule (1996:3) ${ }^{6}$ stated that pragmatics is a study of meaning communicated by speaker and speaker partner that covers the speaker's meaning, implicature, contextual meaning, and expressions about relative distance between speaker and speaker partner.

Rohmadi, et al (2013:9 ${ }^{17}$ had opinion about pragmatics as part of functional linguistic analysis that has language external substances comprehensively. Pragmatics studies about the meaning of someone utterance that express behind it utterance.

There are several pragmatics studies, one of them is speech act theory, that is theory about direct utterance which is used to show the aim of complex interaction. Besides, in pragmatics there is also implicature conversation theory, it means that in the conversation between speaker and speaker partner they are bound by maxims. In other word, if the conversation between speaker and speaker partner are analyzed there would be in the form of interaction that has relevant connection (Jumanto, 2017:36-37).

Besides both of those theories, pragmatics also studies about politeness. Politeness theory presented by Brown and Lavinson (1987) is the most well-known among others. Politeness aspect presented by Brown and Lavinson covers the way to present social distance and role relation differently in communication (Jumanto, 2017:40).

Based on the explanation before, it can be said that language used One of it utterance in using the language is opposing utterance. The language used against the Banjar Language is called baindah ${ }^{4}$. Wibowo $(2015: 35)^{8}$ stated that language has power to reveal reality. It is not only as a communication tool but it can reflect what it seen, felt, and heard by the speaker towards their environment. Based on the introduction, the problem in this study is how does the realization of the application and violation of the politeness opposing utterance in Banjar language based on Brown and Lavinson politeness scale.

Previous research that relevant with this study are Jahdiah (2017) ${ }^{9}$ entitled Strategi dan Fungsi Kesantunan Tindak Tutur Melarang dalam Bahasa Banjar:Tinjauan Pragmatik. This study discusses the strategies used in speech acts regarding positive politeness strategies and negative politeness strategies. The positive politeness strategy adds optimistic attitude, promising something, giving praise, and avoiding conflict. While negative politeness strategies are used to forbid someone indirectly. The functions of speech in speech acts in Banjar language are convivial, collaborative, and conflict. Another study that also discusses politeness in Banjar language is Realisasi Prinsip Kesantunan Direktif Bahasa Banjar by Ahmad Zaini (2009)10 This study discusses the types of politeness directives in banjar language that discuss form, function and strategy.

The Politeness Realization of Opposing Speech in Banjar Languages Based on Brown and Stephen Levinson Scale only discusses implementation and violation of speech act in Banjar language.

${ }^{4}$. Baindah: dalam bahasa Banjar memiliki makna tidak mau melakukan apa yang diinginkan oleh mitra tutur 


\section{METHOD}

This study was done on January 2020 and the data were taken for a month. Based on its paradigm this study uses descriptive method. The techniques used to collect the data are observing, note taking, recording, and interviewing. The data of this study includes all kind of utterances in lots of social communication situation in Banjar family ${ }^{5}$ in South Kalimantan territory. The data are taken whether the family member are having interaction in the family and with others in public place. There are two data resources in this study, they are utterance data and field note taking data. To analyze the data this study uses interactive analysis model by Miles and Huberman (in Wahyu, 1992:15-20)11. This model precisely used because it is relevant with the design of this study. That relevance can be seen on the characteristic of the interactive analysis model, they are (1) can be done in four steps: (a) along the data collection, (b) data reduction, (3) data presentation, and (d) data conclusion; (2) those four steps are happen at the same time, connected, continued, and repeated.

\section{THEORY}

Language politeness is important to be noticed. It is aimed to make a communication runs smoothly. The activity of speaking in all aspects by Keith Allan (in Rahardi,2009) ${ }^{12}$ stated as social dimensional activity. As a process of communication, this speaking process will run well if all the speakers bound actively. Therefore it needs strong cooperation among all the speakers one of them is having good attitude or polite (p.22). In order to make our utterance become polite, each of the speakers should choose natural diction and attitude. Polite utterance can be influence by the aim of the speaker member to maintain people feelings and dignity. Nadar (2009) ${ }^{13}$ said that the concept of keeping the dignity between speaker and speaker partner is by using utterance that doesn't have threatening meaning for the speaker and speaker partner.

The using of politeness in speaking not only determined by the diction but also by other aspects that also determine the level of politeness, for example is age, social distance between the speakers, situation, time, place, and the aim of the utterance. Therefore, in the using of language, it is necessary noticing the context when the language is used. One of the theories in language politeness is presented by Brown and Lavinson.

\section{Brown and Lavinson Politeness Scale}

It has differentiation with Leech $(1983)^{14}$ In Brown and Lavinson politeness model (1987) there are three important scales that determine the low and high of the politeness level in utterance. Those three scales are determined contextually, socially, and culturally, they are (1) social distance between speaker and hearer, (2) the speaker and hearer relative power, (3) the degree of imposition associated with the required expenditure of good and services. Here are the explanations of each scale.

(1) Social distance scale between speaker and hearer is determined by the parameter of age, sex, and sociocultural background. The different of age between the speaker and speaker partner naturally happen when someone is getting older, the level of politeness is getting higher. On contrary, when someone is still young, the level of politeness is getting lower in the activity of speaking. For female, they usually have higher politeness than male. It happens because in the reality female tend to have aesthetic value in their daily life.

(2) The speaker and hearer relative power or power rating is based on the asymmetric position between the speaker and speaker partner. For example, in the room of a

5 . Informan berasal dari desa Limamar dan Desa Lokgabang, Kecamatan Astambul 
hospital, a doctor has a higher power than the patient. In the class, a lecturer has a higher power than the student. In line with that thing, in the street, a policeman has higher power than a doctor when the doctor coincidentally get traffic ticket, and the doctor get higher position towards the policeman when he is hospitalized.

(3) Rank rating or the degree of imposition associated with the required expenditure of good and services is based on the position of one speech act relative to the other. For example, in a very special situation when a woman come to someone house late night then it can be said that it is impolite, moreover it means that she breaks the norm in that community. In the other hand, the same thing will be considered natural when there is chaos and the woman/man is in someone else's house.

\section{ANALYSIS AND DISCUSSION}

Opposing speech act is a speech act that contain of opposing or disagreement towards what is wanted by the speaker partner. It needs politeness in speaking when someone do speech act, but the existence of speech act is consider less polite when it is not wanted by the speaker partner. Here are the data for politeness opposing speech act based on politeness scale by Brown and Lavinson.

Data 1

Mother: Anjurkan bakul ini ka rumah nini Aslam

'Antarkan keranjang ini ke rumah nenek Aslam' 'Take this basket to granny Aslam'

Child : Kaina dululah ulun haur.

'Nanti dulu, saya lagi sibuk' Later, I'm

busy'.

Speech context:

The speaker asks speaker partner

The utterance is said by the speaker partner to the speaker when the speaker asks speaker partner to take the basket to granny Aslam's house. The utterance said by the speaker partner is categorized in opposing utterance because when the speaker partner asked by the speaker, he/she doesn't do it immediately what it said by the speaker. Based on the scale presented by Brown and Lavinson, the utterance in data1 is categorized opposing politeness scale by Brown and Lavinson, that is social distance between speaker and hearer. According to this scale, this politeness is determined by the difference of age, sex, and sociocultural background. The utterance in data 1 is categorized less polite because the speaker partner opposes the speaker when he asks to give the basket to granny.

Data 2

A : Ayu, umpat pang basapida unda handak ka pasar 'Ayo, ikut naik sepeda, saya mau ke pasar'

'Give me a ride, I wanna go to the market'

B : Unda kada kawa babawa ikam.

'Saya tak bisa memboncengmu'

'I can't give you a ride'

Speech context:

The speaker partner is a friend of the speaker, they met on the street.

The utterance Unda kada kawa babawa ikam 'I can't give you a ride' is uttered by the speaker partner when he/she wants to ride with the speaker, but the speaker refuses it. Based on the scale presented by Brown and Lavinson, the utterance in data 2 is categorized polite utterance based on social status level between speaker and speaker partner (the speaker and hearer relative power). Based on this scale, it is said that an utterance is considered polite when the utterance is uttered by a speaker who has higher social level. 
Data 3

A: Uma, kautakanlah nasi ulun handak makan.

'Ibu, ambilkan nasi, saya mau makan.'

'Mom, could you give a spoon of rice, I wanna eat?'

B: Ambil sorang haja.

'Ambil sendiri aja'

'Take it yourself

'Speech context:

The speaker partner refuses speaker partner's asking

The utterance Ambil sorang haja 'Take it yourself' is uttered by the speaker when the speaker asks the speaker partner to take a spoon of rice to the speaker partner but the speaker partner refuses it. This utterance is categorized opposing speech act. The speaker partner opposes the speaker by saying 'Take it yourself'. Based on scale distance between speaker and hearer by Brown and Lavinson this utterance is categorized polite because this utterance determined by the difference of age. The utterance on data 3 is uttered by a mother to her child. A mother is considered polite when she opposes what is asked by her child because there is social distance scale between speaker and speaker partner.

Data 4

A: Wati kita tulakan wayahinian.

'Wati kita berangkat sekarang.

'Wati, let's go right now'

B: Aku koler lagi menunggu kuitan aku handak datang.

'Aku malas lagi nunggu orangtuaku datang.'

'I don't wanna go, I'm waiting my parent.'

Speech context:

The speaker asks speaker partner to go right away

The utterance Aku koler lagi menunggu kuitan aku handak datang 'I don't wanna go, I'm waiting my parent' is uttered when the speaker asks speaker partner to go to the market but the speaker partner refuses it. This utterance is categorized opposing utterance. Based on the politeness scale by Brown and Lavinson and speech act level scale or the degree of imposition with the required expenditure of goods or services, this utterance is categorized polite utterance. Based on the speech act utterance level, it is said that an utterance is categorized polite or not depends on the time when the utterance is uttered. If the utterance is said in unsuitable situation then it can be said that the utterance is impolite. On contrary, when the utterance is said in a suitable situation, it can be said that the utterance is polite.

Data 5

Child: Ma, ulun hari ini mambawa hplah.

'Bu, hari ini saya membawa hp ya.'

'Mom, can I bring mobile phone today?'

Mother: Amun kawa kada usah pang nak ai, kaina diambil guru.

'Kalau bisa tidak usah ya nak, nanti diambil guru.'

'You'd better not, the teacher will take it from you.'

Elder: Kada bulih, jangan. Sudah tahu dilarang masih haja handak mambawa.'

'Tidak boleh, jangan. Sudah tahu dilarang masih saja ingin membawa'

'No, you don't. You know that it is forbidden, do you still want to bring it?'

Speech context;

The speaker asks speaker partner's permission.

The utterance happens in the morning. At that time the speaker asks permission to the speaker partner to bring mobile phone to school. The utterances from the two speaker partners are categorized opposing utterance because they don't allowed the child or the speaker brings 
the mobile phone to school. Based on the politeness scale in social distance scale between speaker and hearer by Brown and Lavinson, this utterance describes similarity.

That similarity is the opposing answer of the first speaker partner. Its answer is more polite than the second speaker partner's answer. The first speaker partner is older than the second speaker partner. The first speaker partner is a mother of the speaker and the second speaker partner. Utterance (5) shows that the first speaker partner uses polite opposing utterance by using diction that have choosing meaning not opposing like it is said by the second speaker partner.

Data 6

A: Jagakan adinglah satumat.

'Jagakan adik ya sebentar'

'Take care of our younger sister for a while, ok?'

B: Ikam handak kamana?

'Kamu mau kemana?'

'Where do you wanna go?'

Speech context:

An elder sister asks her younger brother to take care of their youngest sister for a while.

The utterance Ikam handak kamana? 'Where do you wanna go?'is said by a speaker and speaker partner when the speaker asks speaker partner to take care of their youngest sister for a while but the speaker partner refuses it by saying where does the speaker want to go. This utterance is categorized opposing utterance. The speaker partner opposes what is asks by the speaker. It is based on the politeness scale by Brown and Lavinson, that is social distance between speaker and hearer. According to this scale an utterance commonly determined by the difference of age between the speaker and speaker partner. The utterance in data 3 is stated less polite because based on the age a younger brother who opposes his elder is categorized impolite.

Data 7

Neighbor 1 : Halo, aku nih kahawaian banar, umpat bailing kah?

'Halo, aku ini kesepian sekali, aku ke rumah ya.

'Hello, I' m so lonely, may I go to your home?'

Neighbor 2 : Nah, malam banar, mapailah.

'Nah, malam sekali , maaf ya.'

'Well, it's already late night, sorry.'

Speech context:

The speaker asks permission to the speaker partner to come to his/her home.

This utterance happens between neighbors in the evening. Utterance (7) is the form of asking from speaker to the speaker partner by using asking utterance in the evening. Evening is time to take a rest, so the speaker partner refuses it. Based on the politeness scale by Brown and Lavinson that is rank rating or the degree of imposition associated with the required expenditure of goods or services, and based on the relative power of one speech act to the other, this utterance describes what is done by the speaker partner is natural or appropriate.

That naturalness is opposing speaker partner who doesn't allow the speaker to come to that evening. Speaker partner is considered polite because the answer is suitable with the situation at that time, that is evening. Evening is time to take a rest not receiving a guest.

Data 8

Child : Ma, bulilah ulun bulanja.

'Bu, boleh tidak saya belanja.'

'Mom, may I go shopping?' 
Mother: $\quad$ Bulanja tarus, kada, imit duit. Kira nyamankah nyari duit.'

'Belanja terus, tidak, hemat uang. Kamu kira enak nyari uang.'

'Always shopping, no, save the money. Do you think it is easy to get money.'

Speech context:

The speaker asks speaker partner to go shopping

This utterance happens after school. The speaker is being picked up by speaker partner. At that time the speaker has some money left. He wants to buy something and asks permission to the speaker partner but it was refused by the speaker partner with high tone. That rejection is categorized opposing. Based on the politeness scale by Brown and Lavinson in social distance scale between speaker and hearer it describes incompatibility, that is violence towards politeness.

That incompatibility is the rejection from the speaker partner for not allowing the speaker to buy something by using impolite words. That rejection is categorized opposing because it is not suitable with the speaker's will. The speaker partner also considered impolite because based on the age she should be more polite for she is a mother of the speaker. Moreover, the speaker partner uttered his willing in polite words.

Data 9

The Elder : Ikam nih aku lihat kada balajar-lajar, mainan tarus.

'Kamu ini kau lihat tidak belajar, mainan terus.'

'I haven't see you study for hours, you're just playing.'

The Younger: Jar siapa kada balajar, sudah tadi balajar, kadanya bapadah pang.

'Kata siapa tidak belajar, tadi sudah selesai belajar, masa saya harus bilang'

'Who said that, I'm done, I don't have to tell you.'

Speech context:

The speaker expresses his/her opinion to the speaker partner

This utterance happens in the afternoon. The speaker expresses speaker partner's attitude that is playing all day long. Hearing what the speaker said the speaker partner protest and angry. The speaker partner protest is considered opposing the speaker. Based on the politeness scale by Brown and Lavinson in social distance scale between speaker and hearer or power rating there is violence.

That violence is the power of speaker is higher than the speaker partner. Speaker partner is younger brother and he did violence of politeness because he speaks rudely to the speaker as his elder brother.

Data 10

Friend 1: Baimbai buliklah, bila ikam bulik.

'Barengan ya kalau kamu pulang.'

'We go home together, ok.'

Friend 2: Hah, barang ja, tapi aku handak lakas bulik pang. Ikam lawan nang lain ajagin lah.

'Hah, sembarang aja, tapi aku ingin cepat pulang. Kamu dengan yang lain.

'Ok, up to you, but I wanna get home soon. You can get home with someone else.'

Speech context:

The speaker asks speaker partner to get home together.

The utterance happens in the afternoon after office time. The speaker asks speaker partner to get home together. This utterance shows rejection of the speaker partner to the speaker. Through that rejection it means that speaker partner opposing the speaker. This thing 
describes politeness violation based on politeness scale by Brown and Lavinson in rank rating or the degree of imposition associated with the required expenditure of goods and services based on speech act relative position from one to another.

That violence is seen from the time, it is a perfect time for the speaker asking speaker partner to get home together. As a friend and neighbor it is a natural thing when the speaker partner asking him/her to get home together. Speaker partner who feels burdened answers it in a rude way. The speaker feels uncomfortable hearing the speaker partner's response.

\section{CONCLUSION}

The result of this study shows that opposing speech act in Banjar language consists of the implemention and violation based on Brown and Lavinson politeness scale. Thi implementation and violation based on Brown and Lavinson politeness scale covers social distance between speaker and hearer, the speaker and hearer relative power) or power rating, and rank rating or the degree of imposition associated with the required expenditure of goods or services based on the relative position of speech act from one to another. This result describes that the utterance in Banjar society communication is always suitable and unsuitable with the theory presented by Brown dan Levinson.

\section{ACKNOWLEDGMENT}

We would like to express our gratitude to the seminar commitee who allow us to join and give contribution in this seminar. We also would like to say thank you to the institution who allows us to do this research and follow this seminar. We also would like to express our gratitude to all the informants who are willing to be the part of our research.

\section{REFERENCES}

[1] Jumanto. Pragmatik, dunia linguistik tidak selebar daun kelor.Yogyakarta: Morfalingua. 2007.7p

[2] Wijana, I Dewa Putu. Dasar-dasar pragmatik. Yogyakarta: Andi Yogyakarta. $1996.45 \mathrm{p}$.

[3] Putrayasa, Ida. Bagus. Pragmatik. Yogjakarta: Graha Ilmu. 2015. 50 p.

[4] Kridalaksana, Harimurti. Kamus linguistik. Jakarta: Gramedia.2008. 8 p

[5] Tohmas, J. 1996Meaning in Interaction: An Introduction to Pragmatics. New York:Logman.1996. 22 p.

[6] Yule, George. Pragmatik. Yogyakarta: Pustaka Pelajar. 2006. 3 p.

[7] Rohmadi, Muhammad. Pragmatik Teori dan Analisis. Surakarta: Yuma Pustaka.2013.9 p

[8] Wibowo. Konsep tindak tutur komunikasi. Jakarta: Bumi Aksara.2015.

[9] Jahdiah.Strategi dan fungsi kesantunan tindak tutur melarang dalam bahasa banjar:tinjauan pragmatik. Pusat Kajian Budaya.Universitas Katolik Indonesia Atmajaya.2015. 313-317p.

[10]Akmad, Zaini. Realisasi tindak tutur direktif dalam bahasa banjar .[thesis] Banjarmasin:Pascasarjana Univeristias Lambung Mangkurat.2009.

[11] Wahyu. Pedoman penulisan karya ilmiah. Banjarmasin: FKIP Universitas Lambung Mangkurat. 2006.15-20p.

[12] Rahardi, K. Pragmatik : kesantunan imperatif bahasa Indonesia.2009.22p 
[13] Nadar, F.X. Pragmatik dan Penelitian pragmatik. Yogyakarta: Graha Ilmu.2009.30p

[14] Brown , G. Levinson, S. Politeness. Some Universal in Language Usage. CambridgeUniversity Press.1987. 